\title{
Tersanelerdeki Radyografi Uygulamaları ve Risk Değerlendirmesi
}

\author{
Kağan Yüce ${ }^{1}$, Barış Barlas ${ }^{2}$ \\ 1,2 İstanbul Teknik Üniversitesi, Gemi İnşaatı ve Deniz Bilimleri Fakültesi \\ ${ }^{1}$ (sorumlu yazar), yuce20@itu.edu.tr, ORCID: 0000-0003-1703-9481 \\ 2 barlas@itu.edu.tr, ORCID: 0000-0002-5846-2369
}

\section{ÖZET}

Endüstri, sağlık, güvenlik, tarım, sanat, arkeoloji vb. birçok alanda kullanım alanı bulunan radyografi yöntemlerinin güvenli şekilde kullanılabilmesi için birçok uluslararası kurum ve sivil toplum kuruluşu tarafından çeşitli standartlar geliştirilmiştir. Radyasyonla ilgili standartları ve sınırlamaları belirleyen uluslararası kuruluşların yanısıra her ülkede, radyasyon ile ilgili yetkilendirme, takip ve denetleme işlemlerini yürüten ulusal kurumlar bulunmaktadır. Radyografi yöntemi, ışın kaynağından çıkan iyonize radyasyonun madde içerisinden geçerek film üzerinde görüntü oluşturması esasına dayanmaktadır. Radyografide kullanılan iyonlaştırıı radyasyonun maddeler ve canlılar üzerinde elektriksel, fotokimyasal, flüorışıl ve biyolojik olmak üzere dört temel etkisi bulunmaktadır. Bu etkiler arasında biyolojik etki, canlılar için son derece zararlı ve tehlikeli olmasına karşın; diğer etkiler, insanoğlu için faydalı amaçlarla kullanılmaktadır. Tersanelerde kaynak imalatların kontrolünde sıklıkla kullanılan bu yöntem ile Türkiye tersanelerinde yılda ortalama 8,500 adet çekim yapıldığı hesaplanmaktadır. Bu çalışmada tersanelerde uygulanan radyografi riskleri; cihaz kaynaklı, personel kaynaklı ve organizasyon kaynaklı olarak üç başlıkta incelenmiştir. Belirlenen risklerin 5x5 matris yöntemi kullanılarak risk analizi ve değerlendirmesi yapılmıştır. Risklerin nedenleri ve bu risklere karşı alınabilecek tedbirler açıklanmıştır.

Anahtar kelimeler: Endüstriyel radyografi, iyonize radyasyon, radyasyondan korunma, tersanelerde radyografi uygulamaları, tahribatsız muayene, risk analizi, biçimsel risk analizi.

Makale geçmişi: Geliş 24/06/2021 - Kabul 20/10/2021

https://doi.org/10.54926/gdt.957000 


\title{
Risk Assessment Analysis of Radiographic Testing in Shipyards
}

\author{
Kağan Yüce ${ }^{1}$, Barış Barlas ${ }^{2}$ \\ 1,2 İstanbul Technical University, Faculty of Naval Architecture and Ocean Engineering \\ ${ }^{1}$ (corresponding author), yuce20@itu.edu.tr, ORCID: 0000-0003-1703-9481 \\ 2 barlas@itu.edu.tr, ORCID: 0000-0002-5846-2369
}

\begin{abstract}
There are many international and non-governmental organizations in order to use the radiography method, which has many areas such as industry, health, security, agriculture, art and archeology. In addition to the international organizations that set the standards and limitations on radiation, there are national institutions in each country that carry out authorization, monitoring and inspection procedures regarding radiation. The radiography method is based on the principle that ionized radiation emanating from the radiation source passes through the substance and creates an image. The ionizing radiation used in radiography has four basic effects on substances and humans: electrical, photochemical, fluorescent and biological. Among these effects, although the biological effect is extremely harmful and dangerous for living things; other effects are used for human benefit. This method, which is frequently used in the control of welded manufactures in shipyards, takes an average of 8,500 shots per year in the light of the latest data on shipbuilding projects in Turkey. Considering the risks in the shipyard, the risks of the radiography applied in this study; It has been examined under three headings: device sourced, personnel sourced, and organization sourced. Risk analysis and assessment of the identified risks were made using the $5 \times 5$ matrix method. The reasons for the risks and the measures to be taken against these risks are explained.
\end{abstract}

Keywords: Industrial radiography, ionizing radiation, radiation protection, radiation protection in shipyard, non-destructive testing, risk analysis, formal risk analysis.

Article history: Received 24/06/2021 - Accepted 20/10/2021 


\section{Giriş}

Tahribatsız muayene (Non-Destructive Testing- NDT) yöntemlerinden birisi olan radyografik muayene, günümüzde endüstri, sağıık, güvenlik, tarım, sanat, arkeoloji vb. birçok alanda kullanılmaktadır. Bir ışın kaynağından çıkan iyonize radyasyonun malzeme içerisinden geçerek çeşitli yöntemlerle görüntü oluşturması esasına dayalı bu yöntem, endüstride sıklıkla tercih edilmektedir. Diğer tahribatsız muayene yöntemlerine göre avantajları bulunmasına rağmen en büyük dezavantajı güvenliktir. Ayrıca yöntemin ilk yatırım maliyeti test edilecek malzeme kalınlığına ve türüne bağlı olarak yüksek olabilmektedir.

Radyasyonun ve insan vücuduna olan zararlı etkilerinin keşfedilmesinden sonra, iyonize radyasyonun çalışanlara ve halk sağlığına etkilerini asgari düzeyde tutabilmek maksadıyla bağımsız ve uluslararası bir sivil toplum kuruluşu olan Uluslararası Radyolojik Koruma Komisyonu kurulmuştur (1928). Birleşmiş Milletler bünyesinde ise 1954 yılında atomik radyasyonun etkilerini incelemek ve bu konuda raporlar hazırlamakla görevli bilim komitesi (UNSCEAR, 2021) oluşturulmuştur. İyonize radyasyonun güvenli kullanımı, insan sağlığına etkileri ve bu konudaki kısıtlamaları belirleyebilmek için yasal düzenlemeyi oluşturmak, uluslararası standartları belirlemek ve ulusal mevzuatlar için asgari gereklilikleri belirlemek maksadıyla 1957 yılında Uluslararası Atom Enerjisi Kurumu (IAEA) kurulmuştur. Ülkemizde radyasyonla ilgili faaliyetleri düzenlemek maksadıyla 1956 yılında kurulan Türkiye Atom Enerjisi Kurumu (TAEK), günümüzde Nükleer Düzenleme Kurumu (NDK) adıyla faaliyetlerine devam etmektedir (TENMAK, 2021).

Uluslararası Atom Enerjisi Kurumu bugüne kadar 9000'den fazla bilimsel yayın, rapor ve rehber doküman yayımlamışırı. Bu dokümanlar çoğunlukla nükleer enerji ile ilgili olsa da Uluslararası Atom Enerjisi Kurumu ve Uluslarası Çalışma Örgütü mesleki radyasyondan korunma ile ilgili standartları belirlemiştir (IAEA, ILO, 2018). Uluslarası standartların tavsiyeleri doğrultusunda hazırlanan ve ülkemizde gerçekleştirilen radyasyon ile ilgili faaliyetleri düzenleyen Radyasyon Güvenliği Yönetmeliği yayımlanmıştır. Ayrıca Nükleer Düzenleme Kurumu, endüstriyel radyografinin güvenli bir biçimde uygulanabilmesi maksadıyla Endüstriyel Radyografi Çalışma Kılavuzu yayımlamıştır. İyonize radyasyonun endüstriyel uygulamaları ile ilgili olarak literatürde birçok çalışma bulunmaktadır. Zeyrek (2014), iyonlaştırıcı radyasyon uygulamalarının zararlı etkilerinden korunmaya yönelik genel kavramlar ile temel presipleri irdelemiştir. Pandey vd. (2016), endüstriyel radyografide kullanılan cihazlarda meydana gelebilecek sorunları ve bu durumun oluşturacağı riskleri 'Hata Türleri ve Etki Analizi (FMEA)' yöntemi ile değerlendirmiştir. Çimen vd. (2017), iyonize radyasyonun özellikleri ve olası zararlı etkilerinden korunmaya yönelik alınabilecek önlemleri incelemiştir.

Bu çalışmada, tersanelerde de sıklıkla kullanılan radyografinin iş sağlığı ve güvenliği bakımından oluşturduğu riskleri değerlendirmek ve tersaneler özelinde alınabilecek önlemleri incelemek amaçlanmıştır.

\section{Radyasyon ve Endüstride Kullanımı}

Radyasyon, elektromanyetik dalgalar veya parçacıklar biçiminde enerji yayılımı ve aktarımıdır. Temel olarak radyasyon, iyonlaştırıcı ve iyonlaştırıcı olmayan radyasyon olarak ikiye ayrılmaktadır. İyonlaştırıcı radyasyon, atomlardan veya iyonlaşabilen moleküllerden elektron koparabilirken; iyonlaştırıcı olmayan radyasyon koparamaz. Örnek verecek olursak; görünür ışık, radyo dalgaları, mikrodalga ışınları atomları iyonize edemezken; alfa, beta, $\mathrm{X}$ ve gama ışınları iyonize edebilmektedir (Çimen vd., 2017). Endüstriyel radyografide de iyonlaştırıcı radyasyon kullanılmaktadır. 
İyonlaştırıcı radyasyonun maddeler ve insanlar üzerinde dört temel etkisi bulunmaktadır. Bu etkiler elektriki etki, fotokimyasal etki, flüorışıl etki ve biyolojik etki olarak sınıflandırılmaktadır. Elektriki etki ile iletken olmayan bir madde iyonizasyon ile iletken hale getirilir. Bu özellik kullanılarak radyasyonun ölçülmesi mümkün hale gelmektedir. Fotokimyasal etki, filmli radyografide görüntünün oluşmasını sağlayan gümüş-bromürü $(\mathrm{AgBr})$ iyonlarına ayırarak film üzerinde görüntü oluşmasını sağlar. Flüorışıl etki kullanılarak belirli maddeler radyasyonu görünür hale getirebilmektedir. Bu sayede radyasyondan korunma konusunda fayda sağlamaktadır. Radyasyonun biyolojik etkisi ise insan vücudunda veya çevrede bulunan nötr atomları iyonize hale getirerek çeşitli kimyasal tepkimelere neden olmaktadır. Bu tepkimeler sonucunda, insan ve çevre için geçici ve kalıcı zararlı etkiler meydana gelmektedir. Olumsuz biyolojik etkilerden korunmak maksadıyla oluşturulan radyasyondan korunma sistemleri öncelik olarak radyasyonun kaynağını kontrol altında tutmaktır. Kaynağın kontrolünün sağlanamadığı durumlarda kişi odaklı korunma sistemi uygulanır (Zeyrek, 2014).

Endüstriyel radyografide iyonlaştırıcı radyasyon olarak $X$ ve gama ışınları kullanılmaktadır. Bu ışınlar sayesinde malzemelerin iç kusurları tahribatsız olarak tespit edilebilmektedir. $\mathrm{X}$ ve gama ışınları arasındaki temel farklılık, oluşum şekillerinden kaynaklanmaktadır. X ışınları havası boşaltılmış (vakum) bir tüpte katot tarafından üretilen elektronların anottaki hedef metalde durdurulmasıyla üretilirken, gama ışınları radyoaktif maddelerde çekirdek parçalanması ile meydana gelir. $\mathrm{X}$ ışını üretilebilmesi için elektrik enerjisine ihtiyaç duyulurken, gama ışını üretmek için herhangi bir enerjiye intiyaç duyulmaz. Daha birçok farklılıkları bulunan bu radyasyon kaynakları, ihtiyaç duyulan enerji miktarına veya saha uygulamalarındaki fiziki şartlara bağıı olarak endüstride tercih edilmektedir.

Endüstriyel radyografide kullanılan X ışını cihazları Şekil 1'de görüleceği üzere radyasyonun üretildiği tüp ve bu üretimden dolayı ortaya çıkan ısıyı uzaklaştırmak için soğutma sistemini barındıran bir yapıdır. Cihazda bulunan tüpün gerilimini, akımını ve ışın süresini ayarlamak ve görüntüleyebilmek için de kontrol paneli bulunmaktadır. Gama cihazları Şekil 2'de görüldüğü gibi gama ışınını üreten radyoizotopu muhafaza eden bir yapıdan ibarettir. Cihazın ön ve arkasında bulunan hortum, radyoizotopun dişli mekanizmasıyla ortaya çıkması için kullanılmaktadır.

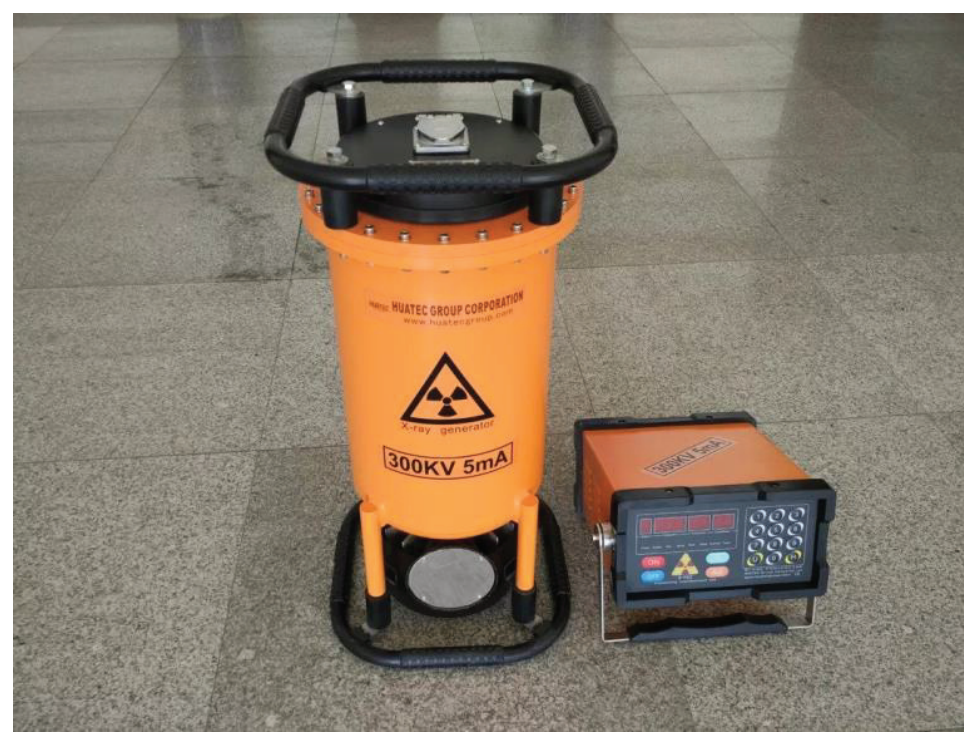

Şekil 1. Endüstriyel uygulamalarda kullanılan taşınabilir X ışını cihazı ve kontrol paneli (Huatec, 2021)

Tahribatsız muayene yöntemlerinden birisi olan endüstriyel radyografi, döküm yoluyla imal edilen malzemelerin, kaynaklı birleştirmelerin, boru hatlarının, basınçlı tankların, çelik ve çelik dışı malzemelerin iç yapısının görüntülenebilmesine imkan vermektedir. $X$ veya gama ışını, malzemenin 
ISSN: 1300-1973, e-ISSN: 2651-530X, Dergi ana sayfası: http://www.gmoshipmar.org/

içerisinden geçirilerek arkasında bulunan film üzerine düşürülür. Bu sayede malzemenin içindeki çatlaklar, boşluklar, kalıntılar, uygulama hataları vb. süreksizlikler film üzerinde görüntülenebilmektedir.

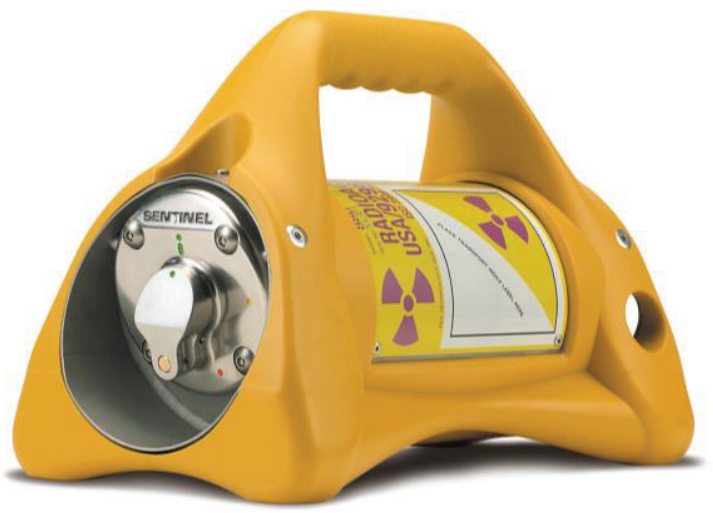

Şekil 2. Endüstriyel uygulamalarda kullanılan bir gama ışını cihazı (Honesdom, 2021)

a)

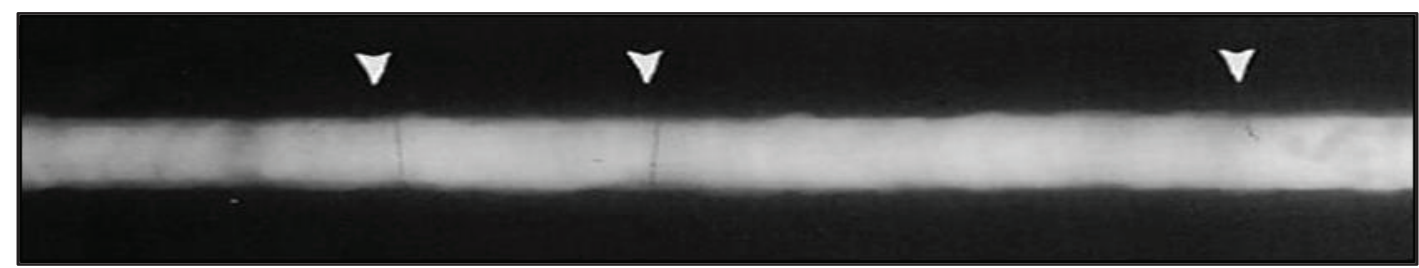

b)

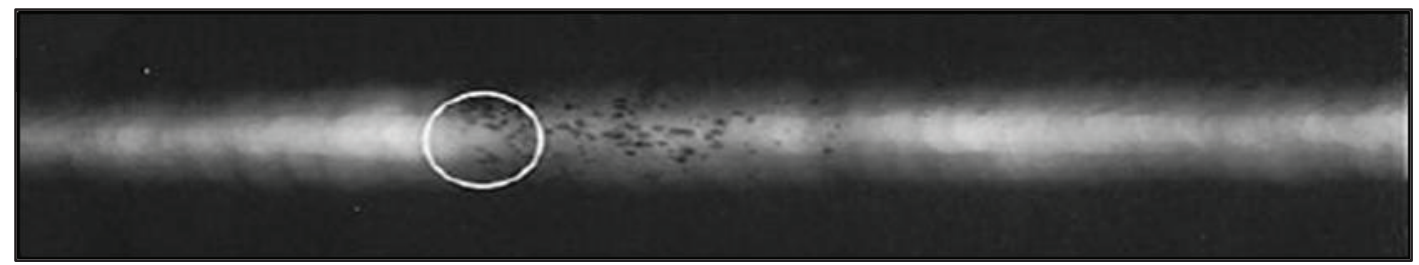

c)

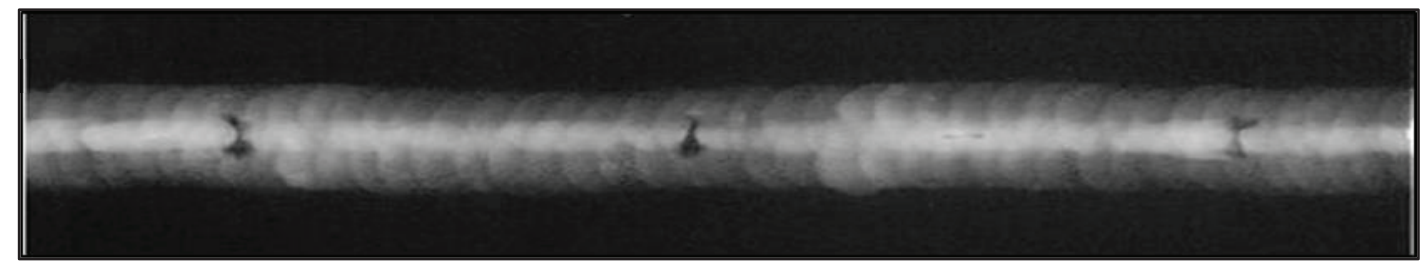

d)

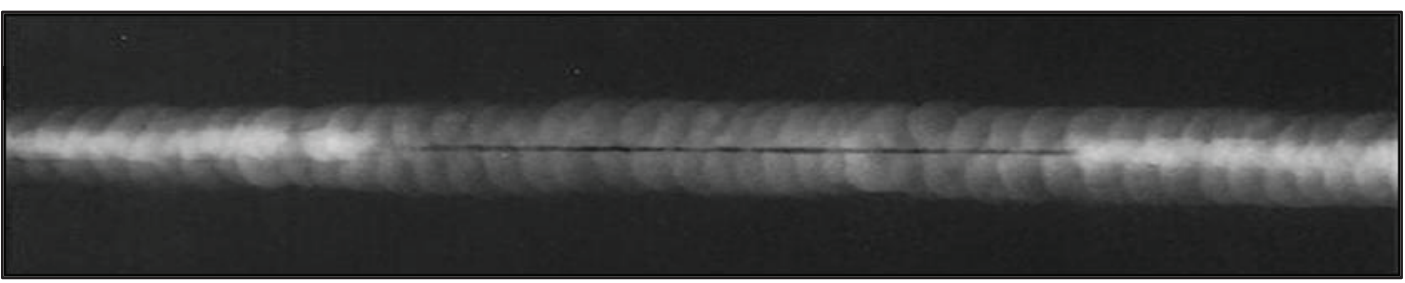

e)

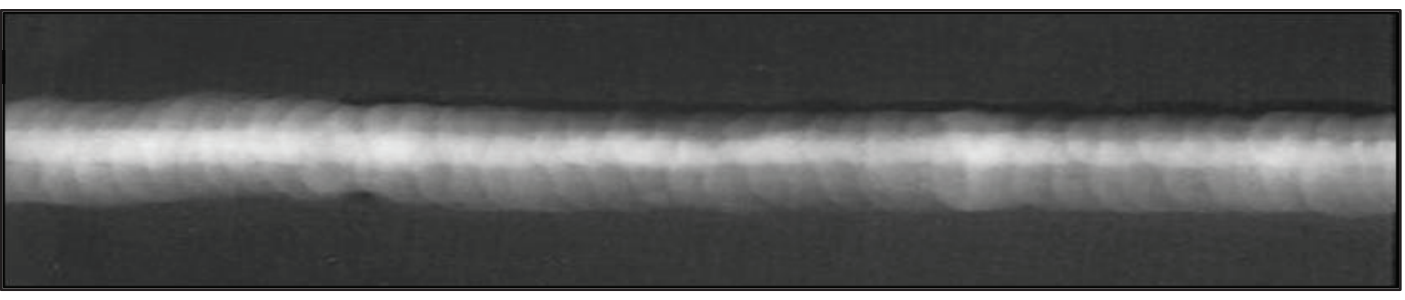

Şekil 3. Radyografi ile görüntülenen süreksizliklerin film üzerindeki görünümleri (DuPont NDT Systems, 1993) 
Şekil 3'de bulunan örnek filmlerde görüldüğü gibi gözle tespit edilemeyen süreksizlikler karakterize edilip, belirli standartlara göre değerlendirilebilir (DuPont NDT Systems, 1993). Şekil 3'de örnek olarak gösterilen kaynak filmlerinden;

(a) filmi kaynak içerisinde bulunan çatlak hatasını,

(b) filmi kaynak sırasında nem veya başka nedenlerle oluşan gaz boşluklarını,

(c) filmi kaynak içerisinde bulunan kum veya cüruf kalıntılarını,

(d) filmi kaynak işleminin kök tarafında yeterli ergitme sağlamaması nedeniyle ergime noksanlığı hatasını,

(e) filmi kaynak sırasında kullanılan akım şiddeti, elektrot, operatör vb. etkilerle oluşan yanma oluğu hatasını göstermektedir.

Tahribatsız muayenede radyografi, kapalı alan ve saha radyografisi olarak iki gruba ayrılmaktadır. Arasındaki temel fark; kapalı alan radyografisinde muayene parçası cihazın yanına taşınırken, saha radyografisinde radyasyon kaynağı muayene edilecek bölgeye taşınır. Bu bakımdan kapalı alanda yapılan çekimler hem ortam şartlarının uygunluğu hem de radyasyonun kontrol altında tutulması yönünden daha avantajıdır. Ancak endüstrinin tabiatı gereği ve özellikle tersaneler özelinde düşünülecek olursa saha radyografisi tercih edilen bir yöntem olmaktadır.

\section{Radyasyon Güvenliği ile İlgili Yönetmelikler}

Radyasyonun zararlı etkilerinden çalışanları, toplumu ve çevreyi korumak için uluslararası ve ulusal kurallar bulunmaktadır. Başta lisans sahipleri, radyasyondan korunma sorumluları ve radyografçılar olmak üzere, endüstriyel uygulamaların yapıldığı ortamlardaki tüm çalışanlar bu kurallara uymak zorundadır. Kuralların yer aldığı yönetmelikler, radyasyon alanlarının sınıflandırılması, çalışma koşullarının belirlenmesi, acil durumlar, radyoaktif kaynağın değişimi, taşınması, saklanması; cihaz seçimi, cihazların kalibrasyonu, yıllık maruz kalınabilecek doz sınırlamaları ve mesleki ışınlamaların takibi konularını kapsar.

Uluslararası Atom Enerjisi Kurumu (IAEA), iyonize radyasyonun zararlı etkilerinden insanları, çevreyi korumak ve üye ülkelerin yerel mevzuatlarında uygulanması için temel güvenlik standartları yayımlamıştır. IAEA'ya ait bu standartlarda, tüm tarafların asgari sorumlulukları, devletin ve yöneticilerin rolü, radyasyonun etkin ve güvenli olarak yönetilmesi, radyasyon faaliyetinin gerekçelendirilmesi, maruz kalınan dozun optimizasyonu, bireysel risklerin sınırlandırılması, mevcut ve gelecek nesillerin korunması, kazaların önlenmesi, acil durumlara hazırlık, kontrolsüz radyasyona karşı önlemlerin belirlenmesi on temel prensip olarak kabul edilmiştir (IAEA, 2014). Uluslararası Atom Enerjisi Kurumu (IAEA)'nun, temel güvenlik stadartlarını esas alarak yayımladığı endüstriyel radyografide radyasyondan korunma rehberi bulunmaktadır. Rehberde, tahribatsız muayenelerde kullanılan endüstriyel radyografinin $X$ ve gama ışınlarıyla güvenli bir biçimde icra edilebilmesi için kapalı alan ve saha uygulamalarında kullanılmak üzere tavsiyeler bulunmaktadır (IAEA, 2011). Uluslararası Radyasyondan Korunma Komisyonu (ICRP), ilk olarak 1977 yılında oluşturduğu Doz Sınırlama Sistemi, ülkeler tarafından kabul görerek uygulanmaya başlanmıştır. Buna göre radyasyondan korunma; gerekçelendirme, optimizasyon ve doz sınırlaması başlığı altında üç temel prensibe ayrılmaktadır. Gerekçelendirme, radyasyon uygulaması sonunda elde edilecek net faydayı; optimizasyon, radyasyon uygulamalarında alınacak doz ile sağlanacak net fayda arasındaki optimizasyonu; doz sınırlaması ise kişilerin ve toplumun yıllık maruz kalabileceği doz miktarının belirlenmesini ifade etmektedir (ICRP, 2007). 
Uluslararası standartların asgari gereklerine uygun olarak her ülke, ulusal mevzuatlarını oluşturmuştur. Ulusal mevzuatlar doğrultusunda iyonize radyasyonun endüstride uygulamalarını kapsayan birçok rehber dokümanda; endüstride kullanılan cihazlar hakkında dikkat edilmesi gereken hususlar, endüstri özelinde ortaya çıkan riskler ve korunma yollarını içeren tavsiyeler bulunmaktadır. Kanada Nükleer Güvenlik Komitesi tarafından hazırlanan Endüstriyel Radyografide Emniyetli Çalışma dokümanı, özellikle endüstride nispeten daha çok kullanılan gama kaynakları ile yapılan çalışmalarda uyulması gereken kuralları, ulusal mevzuatların gerekliliklerini ve operasyon öncesinde ve sonrasında yapılması gereken kontrollerin bulunduğu kontrol listelerini içermektedir (CNSC, 2014). Ülkemizde de iyonize radyasyonun güvenli bir biçimde kullanılması için temel güvenlik standartlarının, kişilerin maruz kalabileceği azami doz miktarlarının ve lisans sahibinin, radyasyondan korunma sorumlusunun, radyografçıların sorumluluklarının belirlendiği Radyasyon Güvenliği Yönetmeliği bulunmaktadır (Radyasyon Güvenliği Yönetmeliği, 2000). Endüstride kullanılan radyasyonun güvenli kullanımına yönelik olarak da 2005 yılında Endüstriyel Radyografide Radyasyondan Korunma ve Lisanslama Yönetmeliği yayımlanmıştır (Endüstriyel Radyografide Radyasyondan Korunma ve Lisanslama Yönetmeliği, 2005). Bu Yönetmelikte, radyasyondan korunma ile ilgili olarak:

Madde 39- Radyasyondan korunma sorumlusu ve radyografcılar tarafından bu Yönetmeliğin 38 inci maddesinde belirtilen endüstriyel radyografi çalışma yöntemlerinin uygulanmasında, kaynak değişimlerinde, taşımalar ile bakım ve onarımlarda, sızıntı testlerinde, ölçüm ve kontrollarda radyasyon korunmasının aşağıda verilen üç temel ilkesi uygulanır:

a) Zaman: Radyasyon kaynağı veya kaynakları bulunduran cihazlar ile olan işlem mümkün olan en kısa sürede tamamlanır.

b) Uzaklık: Radyasyon doz hızının, uzaklığın karesi ile ters orantılı olarak azaldığı göz önünde bulundurularak, radyasyon kaynağı veya kaynakları bulunduran cihazlardan yeterli uzaklık sağlanır.

c) Zırhlama: Maruz kalınacak dozu azaltmak için zaman ve uzaklık ilkelerinin yeterli olmaması durumundaki çalışmalar, kurşun, beton gibi soğurucu özelliği olan yoğun malzemelerden yapılmış engeller arkasından yürütülür.

Radyasyondan korunma ile ilgili bu üç madde, tersanelerdeki uygulamaların güvenli bir biçimde yürütülmesi için de geçerlidir. Tersanelerdeki uygulamalarda radyasyon kaynağı ile olan sürenin minimumda tutulması, mümkün olduğu kadar kaynak ile operatör arasındaki mesafenin uzun tutulması ve radyasyonun etkilerinden korunmak için sac veya beton gibi malzemelerin arkasına saklanılması ile radyasyondan korunulmaktadır.

\section{Radyografinin Tersanelerdeki Uygulamaları}

Dökümden kaynağa birçok imalat yöntemini bir arada bulunduran gemi inşa sanayi, endüstrinin önemli bir koludur. Bu doğrultuda hem üretilen malzemelerin kontrolü hem de işletme halinde bulunan malzemelerin periyodik kontrolleri için tahribatsız muayene yöntemleri azami önem arz etmektedir. Gemi inşaatında kullanılan kaynaklı birleştirmelerin kontrolü de tahribatsız muayene yöntemleriyle yapılmaktadır. Yüksek ısı girdisiyle birleştirilen iki malzeme arasında, yüzeysel kusurlar ve iç kusurlar ortaya çıkmaktadır. Yüzeysel kusurların tespiti için gözle, penetrantla, manyetik parçacıkla muayene yöntemleri kullanılırken; gözle tespiti mümkün olmayan iç kusurların tespiti için temel olarak ultrasonik, radyografik ve girdap akımları yöntemleri mevcuttur. Bu yöntemler sayesinde, gerekli koşulların sağlanması koşuluyla iç kusurlar tespit edilebilmektedir. Radyografi, ince parçalara uygulanabilmesi, kusurların karakterizasyonu, muayene sonucunda görsel kanıt 
oluşturulabilmesi ve muayeneyi yapan operatör etkisinin nispeten düşük olması nedeniyle tercih edilmektedir.

Gemi klas kuruluşlarının tekne yapım kuralları incelendiğinde, kaynaklı birleştirmelerin tahribatsız muayene ile kontrol edilmesi gerektiği görülmektedir. Türk Loydu Cilt A Kısım 3 Bölüm 12'e göre kaynaklı birleştirmelerin tahribatsız muayene kapsamı, gemi tipine ve yapısına bağlı olarak aşağıdaki formülle hesaplanmaktadır (Türk Loydu, 2019).

$$
A=0.8 * A_{L} * c_{p} *\left(A_{B} * c_{B}+A_{H} * c_{H}\right)
$$

Burada,

$$
\begin{gathered}
A_{L}=L /\left(16 * a_{0}\right), \\
L=\text { Gemi boyu, } \\
a_{0}=L / 500+0.48 \leq 1.0[\mathrm{~m}],
\end{gathered}
$$

Enine posta sistemi için;

Enine ve boyuna karışık posta sistemi için;

Boyuna posta sistemi için;

$$
\begin{gathered}
A_{B}=B / 2.5, \\
B=\text { Gemi genişliği, } \\
A_{H}=H / 2.5, \\
H=\text { Derinlik, }
\end{gathered}
$$

$$
\begin{array}{ll}
\text { Tek cidarlı tankerler ya da benzer ana çerçeve kesitleri için; } & \mathrm{C}_{\mathrm{B}}=1.0, \\
\text { Kuru yük ve dökme yük gemileri için; } & \mathrm{C}_{\mathrm{B}}=1.3, \\
\text { Konteyner gemileri ve çift cidarlı tankerler (kimyasal) için; } & \mathrm{C}_{\mathrm{B}}=1.5, \\
\text { Kuru yük gemileri için; } & \mathrm{C}_{\mathrm{H}}=0.5, \\
\text { Tankerler, konteyner gemileri ve dökme yük gemileri için; } & \mathrm{C}_{\mathrm{H}}=0.5, \\
\text { Illave boyuna perdesi olan çift cidarlı tankerler için; } & \mathrm{C}_{\mathrm{H}}=0.5,
\end{array}
$$

Örnek vermek gerekirse, 100 metre boyunda, 25 metre eninde ve 20 metre derinliğe sahip bir yüzer havuz inşası için Denklem 1'e göre;

$$
\begin{gathered}
A_{L}=9.19, A_{B}=10, A_{H}=8, \\
C_{B}=1.3, C_{P}=2.0, C_{H}=0.5, \\
A=0,8 *(9,19) *(2,0) *(10 * 1,3+8 * 0,5)=250 \\
-76-
\end{gathered}
$$


ISSN: 1300-1973, e-ISSN: 2651-530X, Dergi ana sayfası: http://www.gmoshipmar.org/

(a) Perde kaynak radyografisi

(b) Dış kaplama armuz kaynak radyografisi

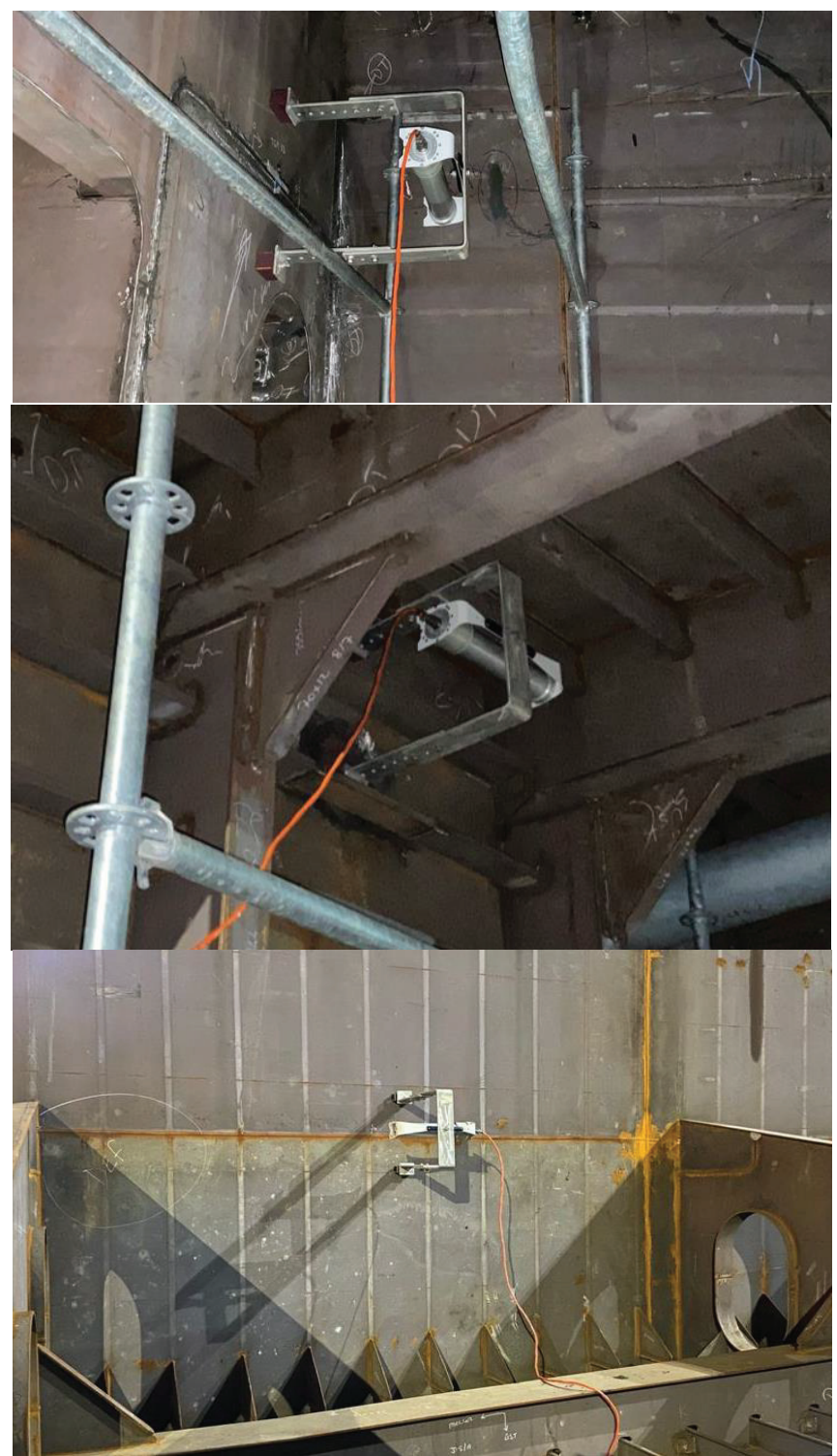

Şekil 4. Endüstriyel radyografinin gemi inşa uygulamalarından görünüşler.

radyografik muayene sayısı (A) 250 adet olmaktadır. Bu formül ile belirlenen radyografik muayene sayısı, sızdırmaz bölmeleri oluşturan su geçirmez perdeler üzerindeki kaynaklara, blokların birleşim yerlerine, enine ve boyuna kaynakların birleşim noktalarına ve yapısal elemanlar üzerindeki kaynaklara öncelik vermek suretiyle tahribatsız muayene bölgeleri tespit edilmektedir. Her gemi inşa projesinde uygulanan radyografik muayeneler, klas kuruluşlarından onaylatılması gereken tahribatsız muayene planına göre gerçekleştirilir.

Türkiye'de 2020 yılı itibariyle Marmara ve Batı Karadeniz bölgelerinde yoğun olmak üzere, faal 82 tersane bulunmaktadır. Gemi inşa sanayisinin içerisinde bulunduğu küresel ekonomik sisteme göre üretim sayısı belirlenen tersanelerde, 2008-2019 yılları arasında yılda ortalama 34 gemi inşa edilmiştir (Deniz Ticaret Odası, 2020). İnşa edilen bu projeler kapsamında gerçekleştirilen tahribatsıı muayeneler için ortalama 250 radyografik çekim yapıldığı kabul edilecek olursa, tersanelerdeki gemi inşa projeleri kapsamında yıllık ortalama 8,500 adet radyografik çekim yapılmaktadır.

Tersanelerde gerçekleştirilen gemi inşa projelerinde tahribatsız muayeneler kalite kontrol departmanının sorumluluğundadır. Ancak tersaneler, radyografi uygulamaları için radyasyon cihazını bünyelerinde bulundurmamaktadır. Bunun yerine muayeneler, münferit olarak alt yükleniciler 
tarafından gerçekleştirilmektedir. Projenin tahribatsız muayene planına göre alt yüklenici ile koordine kurulup, muayenesi yapılacak kaynak işleminden sonra, iş sağlığı ve güvenliği bakımından ve iş planlamalarının aksamasının önüne geçmek maksadıyla gece saatlerinde ya da öğle paydoslarında radyografik muayene gerçekleştirilir. $X$ ya da gama ışın kaynağı kullanımı radyografçı tarafından tahribatsı muayene prosedürüne göre belirlenecek olup, saha şartlarından dolayı genellikle gama ışın kaynağı kullanılmaktadır. Tersane ortamına aşina olmayan personelin muayene işlemini gerçekleştirmesi, muayenenin yapıldığı zaman ve gama kaynak kullanımı radyografi işleminin güvenli biçimde uygulanmasında ciddi riskler barındırmaktadır.

Saha radyografisinin uygulandığı tersaneler, birçok branşın aynı anda ve kısıtlı alanlarda birlikte çalışmak durumunda kaldığı, buna karşın zamanın ve maliyetin azami önemli olduğu iş alanlarıdır. Şekil 4'de endüstriyel faaliyetlerde kullanılan radyografi cihazının tersane şartlarındaki kullanımı gösterilmektedir: (a) perde kaynak radyografisi, (b) dış kaplama armuz kaynak radyografisi ve (c) iç cidar perde kaynak radyografisi. Bu özellikleriyle diğer endüstri kollarından ayrılan tersanelerde, radyografi gibi yüksek risk içeren faaliyetlere iş sağlığı ve güvenliği bakımından azami önem gösterilmesi gerekmektedir. Öncelikle radyasyonla ilişkili risklerin ve radyolojik olmayan risklerin tersane şartlarına göre belirlenmesi, değerlendirilmesi ve buna göre önlemler alınması, oluşabilecek kazaların önüne geçilebilmesi için önemli bir gerekliliktir.

\section{Tersanelerde Radyasyon Kaynaklı Riskler ve Korunma Yolları}

Endüstride uygulanan radyografinin sahip olduğu potansiyel risklerin, tersaneler ve gemiler için özel olarak değerlendirilmesi gerekmektedir. Bu kapsamda endüstriyel radyografinin tersanelerdeki uygulamalarında ortaya çıkan riskleri üç ana başıkta incelemek mümkündür.

- Cihaz kaynaklı riskler

- Personel kaynaklı riskler

- Organizasyon kaynaklı riskler

\subsection{Cihaz kaynaklı riskler}

Radyografide kullanılan X ve gama ışını üreten cihazların kullanılması ve taşınabilmesi için Nükleer Düzenleme Kurumu (NDK)'ndan lisans alınması gerekmektedir. Ülkemizde 2019 yılında lisanslı endüstriyel radyografi cihazı sayısı 784 adet iken bu sayı 2010 yılında 642 adetti (NDK, 2019; NDK, 2020). Aynı zamanda NDK sorumluluğunda icra edilen Endüstriyel Radyografide Radyasyondan Korunma Sorumlusu eğitimi ile yetkilendirilen personel sayısı 2010 ila 2017 yılları arasında toplam 1430 kişidir (Zeyrek ve Babayiğit, 2016; Zeyrek ve Akbıyık, 2020). Buna göre endüstride kullanılan radyografi cihazları sayısı artışının eğitim alan personel sayısına göre nispeten az olmasının nedeni radyografi cihazlarının uzun yıllar kullanılması çıkarımı yapılabilir. Bu durum da radyografi cihaz bakımının önemini arttırmaktadır. Eğer cihaz bakımları düzenli ve kapsamlı olarak yapılmazsa bu durum iş güvenliği bakımından riskler oluşmaktadır.

X ışını cihazlarındaki soğutma ünitesinde meydana gelen bir arıza, cihazın çalışmamasına ya da muayene sırasında istenilen enerji düzeyine ulaşılamamasına neden olmaktadır. Cihaz ile kontrol ünitesi arasındaki elektriksel bağlantıyı oluşturan kabloların da hasar görmesi elektrik iletiminde sorun oluşturacaktır. $X$ ışının üretiminin durmadan devam etmesi gibi elektrik iletiminde oluşacak sorunlar, operatör ve çevre için ciddi risk unsurudur. 
Gama ışını cihazları, yüksek enerjide iyonize radyasyon yayan izotopun muhafaza edildiği kapsül ile izotopu uzaktan kumanda edilerek bu kaynağın kapsülden dışarı çıkmasını sağlayan, içerisinde dişli sistemi barındıran hortumdan ibarettir (Pandey vd., 2016). Cihazın basit yapısına karşın üzerinde barındırdığı bağlantı elemanları, pimler ve yaylarda meydana gelen aşınma, korozyon, kırılma, çatlak vb. hatalar kaynağın hareketini engellemesine, kontrolden çıkmasına, kaybolmasına neden olabilmektedir. Ayrıca kapsülün saha şartlarından dolayı eskimesi ve koruyuculuğunu yitirmesi nedeniyle kaynak kapsüldeyken de ortama ışın yaymaya devam edebilir. Bu durumu önlemek için cihaza düzenli olarak sızıntı testleri yapılmalıdır.

Aktif ve pasif olarak doz ölçümü yapılan cihazların kalibrasyonlarının ve bakımlarının yapılmaması da ortamdaki radyasyonun tespitini engelleyeceğinden operatör ve diğer çalışanlar için risk oluşturmaktadır.

Cihaz kaynaklı riskler endüstriyel radyografideki tüm sektörler için ortak olarak bulunsa da, muayene sırasında kullanılan tüm cihazların lisanslarının olması, gerekli standartları sağlaması ve bakımlarının düzenli yapılması iş güvenliği bakımından azami önem arz etmektedir. Ayrıca bu hususların çalışma öncesinde tersanede bulunan yetkililer tarafından kontrol edilmesi, çalışma sırasında ve sonunda kullanılması gereken ölçüm cihazlarının kalibrasyonlarının olma durumunun denetim altında tutulması gerekmektedir.

\subsection{Personel kaynaklı riskler}

Endüstriyel radyografide kullanılan cihazlara bağlı risklerin bu cihazları kullanan operatör tarafından da bilinmesi gerekmektedir. Bu nedenle NDK'nın düzenlediği Radyasyondan Korunma Eğitimi'nin radyografi operatörlerinin ve radyasyondan korunma sorumlusunun alması zorunludur. Bu eğitim sayesinde personelin kullandığı cihaz hakkında ayrıntılı bilgi sahibi olması, uyması gereken yasal zorunlulukları bilmesi, radyasyondan korunma metotlarını ve ölçüm yöntemlerini kavraması, acil durumlarda yapılması gerekenleri bilmesi sağlanmaktadır. Alınan eğitimler; güncel gelişmelere, uluslararası kuruluşların tavsiyelerine, yasal mevzuatların değişmesine bağlı olarak periyodik olarak yenilenmelidir. Tersanelerde uygulanan radyografi muayenelerinde bahse konu eğitimi almış, yetkili ve belgeli personelin dışında yetkisiz kişilerin çalışması iş güvenliği bakımından ciddi risk unsurudur. Bu durum tersane yetkilileri tarafından denetim altında tutulmalıdır.

Tersanelerde uygulanan radyografik muayenelerde, muayene bölgesinde veya yakınlarında farklı birimlerden personelin bulunma olasılığı vardır. Radyografi ile ilgisiz personelin radyasyondan etkilenmesi riski; tersanede uygulanan radyografi işlemleri ve radyasyonun etkilerinin diğer çalışanlar tarafından bilinmesi ile önlenebilir. Bu nedenle tersanede çalışan personelin radyasyon ve etkileri hakkında bilgi sahibi olması, iş sağlığı ve güvenliği bakımından büyük önem arz etmektedir.

Herhangi bir duyu organıyla tespiti mümkün olmayan radyasyonun tespiti için doz ölçüm cihazları kullanılmaktadır. Doz ölçüm cihazları aktif ve pasif olarak iki gruba ayrılmaktadır. Aktif doz ölçüm cihazları, ortamdaki mevcut dozun anlık ölçümünü yapan önemli bir araçtır. Muayene sırasında ortamda radyasyon olması durumunda sesli ikaz verebilen bu cihazların kullanılması, kalibrasyonlarının yapılarak doğru ölçüm yapmasının sağlanması ve herhangi bir arızaya karşı yedek doz ölçüm cihazının muayenelerde bulundurulması personel kaynaklı riskleri minimize etmektedir. Pasif doz ölçüm cihazları ise personelin maruz kaldığı dozun yasal sınırlar altında olup olmadığının belirlenebilmesi için NDK tarafından takibi yapılan cihazlardır. Uluslararası Radyasyondan Korunma Komisyonu (ICRP)'nun 2007 yılında yayımladığı tavsiyelere göre, çalışanların tıbbi amaçlı radyasyon 
haricinde maruz kalabileceği maksimum doz miktarları yıllık 20 mSv değerini aşmamalıdır (ICRP, 2007).

Radyografik muayenelerde maruz kalınan radyasyonu asgari düzeyde tutmak maksadıyla personelin alması gereken bazı tedbirler bulunmaktadır. Tersanelerde radyografik muayene bölgesi; inşa halinde bulunan bir gemi, faal bir gemi ya da tersanede imal edilen bir konstrüksiyon olabilir. Bu durum, radyografik muayene sahasının kontrol altında tutulmasını zorlaştırmaktadır. Ayrıca radyografi ile ilgisiz kişilerin de doz alması gibi riskleri oluşturmaktadır. Radyasyondan Korunma Yönetmeliğine göre radyografik muayene yapılacak alan doz seviyelerine göre şeritlerle ayrılmalıdır. Denetimli alan olarak ayrılacak bölge, giriş ve çıkışın radyasyon korunma sorumlusunun denetimine tabi olduğu ve doz ölçüm cihazlarının kullanımının zorunlu olduğu alanlardır. Denetimli alan, radyasyondan korunma sorumlusu tarafından kaynağın aktivitesine ve ışın şiddeti değerine göre belirlenerek şeritlerle ayrılmalıdır. Ayrıca denetimli alan uyarı işaretleriyle donatılmalı, sesli ve ışıklı uyarı cihazları kullanılmalıdır.

Gama cihazları kullanımı durumunda radyoaktif kaynaktan çıkan radyasyon her yöne saçılmaktadır. Radyasyonun kontrolsüz olarak etrafa saçılmasını önlemek amacıyla yönlendiriciler (collimator) bulunmaktadır. Bu sayede iyonize radyasyon, muayene alanına yönlendirilerek, radyasyonun ilgisiz alanlara dağılması önlenebilmektedir. Radyografik muayenede görevli personel arasındaki iletişimin etkin olmaması iş sağlığı ve güvenliği bakımından ciddi riskler barındırmaktadır. Muayenede film değiştirme işlemi ya da kaynağın yeniden konumlandırılması sırasında etkin iletişim yetersizliği nedeniyle radyasyonun gerekli önlemler alınmadan ortaya çıkarılması, muayene personelinin ciddi radyasyon almasına neden olabilir. Bu durumu önlemek maksadıyla muayenede görevli personel sayısının optimum düzeyde tutulması ve çalışanlar arasında etkin iletişimin sağlanması gerekmektedir. Özellikle gama ışını cihazların kullanıldığı muayenelerde kaynağın kontrolden çıkması, düşmesi ve kaybolması gibi durumlar ortaya çıkabilmektedir. Muayene sırasında oluşabilecek acil durumlara karşı muayene personelinin yapılması gerekenleri bilmesi gerekir. Acil durumlara müdahale için gerekli ekipmanların muayene sırasında bulundurulması, tersanelerdeki yetkili birimlerce kontrol edilmelidir.

\subsection{Organizasyon kaynaklı riskler}

Endüstriyel radyografinin tersanelerdeki uygulaması sırasında, tersane yönetiminin, planlama, işletme, kalite ve kontrol birimleri ile iş sağlığı ve güvenliği biriminin sorumlulukları bulunmaktadır. Bu sorumluluklara bağlı olarak ortaya çıkabilecek riskler, organizasyon kaynaklı riskler olarak tanımlanmıştır. Tahribatsız muayene kapsamında uygulanacak radyografi uygulamasının güvenli bir biçimde icrası için birçok hazırlık aşaması gereklidir. Tahribatsız muayene birimi ya da yüklenicisi ile projenin ilk aşamalarından itibaren koordine kurulmalı, muayenenin güvenli olarak icrası için gerekli ön şartlar ve gereklilikler sağlanmalıdır. Bu sayede cihaz ve personel organizasyonu sağlıklı bir biçimde gerçekleştirilmekte; cihaz ve personel kaynaklı riskler önemli oranda azaltılmaktadır.

Tersanelerde proje bazlı uygulanan radyografi için iyi bir planlamaya intiyaç vardır. Uygulama esnasında oluşturulacak denetimli alanda radyografi ile ilgisiz kişilerin bulunmaması gerekmektedir. Gerekli iş planlamalarının yapılarak bu alanlarda yapılacak çalışmalar planlanmalıdır. Aksi taktirde bu durum ilgisiz kişilerin doz almasına neden olabilmektedir. Ayrıca muayene için gerekli zaman, organizasyon tarafından sağlanmalıdır. Zaman kısıtlamasının olduğu muayene işlemlerinde iş güvenliği ikinci plana atılmakta ve bu durum ciddi risk oluşturmaktadır. 
Tersanelerde radyografik muayene işlemleri genellikle diğer personelin iş sahasında bulunmadığı, öğle arası ya da gece vardiyalarında gerçekleştirilmektedir. Tersanenin gerekli birimleri tarafından radyografik muayene süresince kontrol altında tutulması gereken hususların takibi zorlaşmaktadır. Zamanlamadan dolayı, yapılan işlemlerde cihaz ve personel kaynaklı riskleri önemli oranda arttırabilecek denetim eksikliği durumu ortaya çıkmaktadır. Denetim eksikliği durumunda radyografik muayenede görevli personelin iş sağlığı ve güvenliği kurallarına uyma durumunun kontrolü ve kullanılan cihaz ve ekipmanların uygunluğunun kontrolü gibi hususlarda zaafiyet yaşanmaktadır.

Radyografi uygulamalarında uygun ortam ve çalışma şartları tersane organizasyonu tarafından sağlanmalıdır. Denetimli bölgenin kontrolü, uyarı ve işaretlerinin görülmesi, radyasyon kaynağının kontrolü, doz ölçüm cihazlarının kullanımı için aydınlatma önemli bir husustur. Yeterli aydınlatmanın sağlanmadığı durumlarda sadece radyolojik değil radyolojik olmayan risklerin de ortaya çıkma ihtimali artmaktadır. Ayrıca radyografi personelinin ve cihazlarının çalışma güvenliğini sağlayabilmek için uygun çalışma iskelesinin kurulması gerekmektedir.

Tersane ortamında, radyolojik olmayan ancak radyografi muayenesinin tehlikesini artıracak birçok risk bulunmaktadır. Gemi, yüzer havuz vb. kapalı alanlarda yapılan muayenelerde radyasyon alanları doğru olarak belirlenmelidir. Gemi içerisinde çekim yapılan bölmede iş güvenliği sağlanırken; yüksek enerjili iyonize radyasyon, bölmeyi ayıran sacın arkasına ulaşabilmektedir. Bu nedenle çekim yapılan bölgenin etrafındaki bölmelerde de iş güvenliğinin sağlanması gerekmektedir. Ayrıca açık alanda yapılan çekimlerde kötü hava koşullarının hem personel üzerinde hem de cihazlar üzerinde olumsuz etkileri bulunmaktadır. Bu etkiler personel ve cihaz kaynaklı riskleri ortaya çıkardığından olumsuz hava etkilerinin asgari düzeye düşürülmesi tersane organizasyonu tarafından sağlanmalıdır.

Organizasyon tarafından yüksek riskli iş kolunda bulunan tersanelerde risk değerlendirmesinin yapılması zorunludur. Yapılan risk değerlendirmesinin, tersanede bünyesinde radyografi birimi olmasa bile radyasyondan korunmayı kapsaması gerekmektedir. Tersane ortamında bulunan radyolojik olmayan riskleri de göz önünde bulundurularak yapılacak risk değerlendirmesi, tersanede yapılacak radyografi uygulamalarında muayene ortamına aşina olmayan yüklenici personelin farkındalığı arttırılarak, muayene operatörünün güvenli çalışması için önemli bir uygulamadır.

\section{Risk Analizi}

Endüstrinin diğer kollarında olduğu gibi endüstriyel radyografinin de güvenli biçimde icrası; operatörlerin, çalışanların, toplum sağlığı ve iş güvenliği için risk analizleri yapılmaktadır. Tesislerde çeşitli yöntemlerle risk analizleri yapılarak, radyolojik ve radyolojik olmayan riskler belirlenmekte; tespit edilen riskler, önlenebilir ve uzaklaştırılabilir hale gelmektedir. Bu sayede çalışanlar, içerisinde bulunduğu tesisin riskleri hakkında farkındalığı artmaktadır. Çalışanların güvenli bir ortamda çalışmalarından sorumlu yöneticiler, iş sağlığı ve güvenliği konusunda doğru ve etkili kararlar verebilmektedir. Ayrıca iş sağlığı ve güvenliğinden sorumlu denetim birimleri tarafından yapılan kontrol ve denetim işlemleri kolaylaştırılmaktadır.

$\mathrm{Bu}$ çalışmada tersanelerde uygulanan endüstriyel radyografinin risk analizini yapmak için $5 \times 5$ analiz matrisi yöntemi kullanılmıştır. Bu yöntemde risklerin seviyeleri, olasılık ve şiddetlerine göre belirlenmektedir. Belirlenen riskler çok yüksek, yüksek, orta, düşük ve çok düşük olarak beş gruba ayrılır. Risklerin değerlendirilmesinde kullanılan olasılık ve şiddet parametrelerinin ölçütleri Tablo 1 'de olduğu gibidir. Buna göre iki yılda bir ve kabul edilebilir seviyede radyasyon maruziyeti çok düşük, yılda bir ve ayakta tedavi gerektiren sağlık sorunları düşük, üç ayda bir ve tıbbi tedavi gerektiren sağlık problemleri orta, ayda bir ve yüksek radyasyon maruziyeti yüksek, haftada bir ve çok 
Tablo 1. Risk analiz matrisi için seviye tanımları

\begin{tabular}{|c|c|c|}
\hline RisK & OLASILIK & ŞIDDET SEVIYESI \\
\hline ÇOK DÜŞÜK & İki yılda bir & Kabul edilebilir seviyede radyasyon maruziyeti \\
\hline DÜŞÜK & Yılda bir & $\begin{array}{l}\text { Ayakta tedavi gerektiren ateş, mide bulantısı, } \\
\text { kusma gibi vücut reaksiyonları }\end{array}$ \\
\hline ORTA & Üç ayda bir & Tıbbi tedavi gerektiren yanıklar \\
\hline YÜKSEK & Ayda bir & $\begin{array}{l}\text { Yüksek radyasyon maruziyeti, ciddi yaralanma, } \\
\text { meslek hastalığı }\end{array}$ \\
\hline ÇOK YÜKSEK & Haftada bir & $\begin{array}{l}\text { Çok yüksek radyasyon maruziyeti, doku/organ } \\
\text { kaybı }\end{array}$ \\
\hline
\end{tabular}

Tablo 2. Risk derecelendirme matrisi

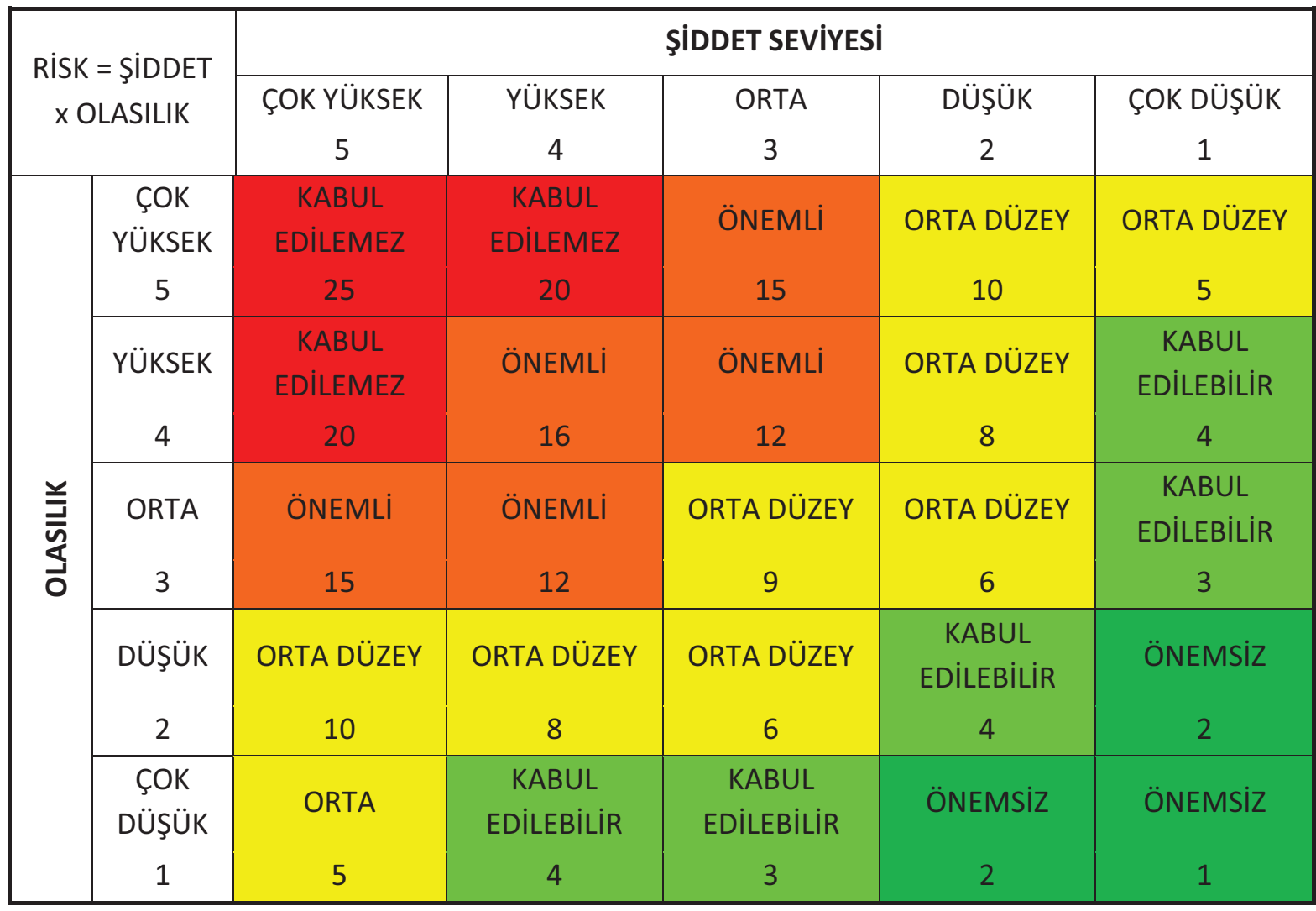

yüksek radyasyon maruziyeti de çok yüksek olarak kabul edilmiştir. Meydana gelme sıklıkları ve şiddet seviyeleri belirlenen riskler, sahip oldukları olasılık ve şiddet seviyelerine göre sayısal olarak çarpılıp Tablo 2'e göre derecelendirilmektedir. Derecelendirilen riskler ise önemsiz, kabul edilebilir, orta düzey, önemli ve kabul edilemez riskler olarak beş grupta kategorize edilip, gerekli eylem planı oluşturulmaktadır (Okumuş ve Barlas, 2016).

Tersanelerde uygulanan radyografinin $5 \times 5$ analiz matrisi yöntemiyle yapılan risk değerlendirmesi Tablo 3'te gösterilmektedir. Bu değerlendirmede ışın kaynağının $X$ ya da gama ışını olduğuna bakılmaksızın tehlikeler sıralanmıştır. Olasılık ve şiddet seviyelerine göre derecelendirilen riskler sonuç sütununda skorlarına göre renklendirilmiştir. 
ISSN: 1300-1973, e-ISSN: 2651-530X, Dergi ana sayfasI: http://www.gmoshipmar.org/

Araştırma Makalesi

Tabloda sıralanan tehlikelerin sonucunda operatörlerin, çalışanların, toplumun ve çevrenin iyonize radyasyona maruz kalma riski bulunmaktadır. Özellikle operatörlerin radyografik muayene işlemini gerçekleştirdiği sahayı tanımaması, sahaya tam olarak hakimiyet sağlayamaması ve radyolojik olmayan riskler konusunda bilgi sahibi olmaması nedeniyle ortaya çıkan riskler hakkında acil olarak tedbir alınması gerekmektedir. Ayrıca tehlikeler arasında oluşum sıklığı düşük ama şiddet seviyesi yüksek riskler, değerlendirme sonucu orta düzey olmasına rağmen önlem alınması gereken tehlikelerdir.

Tablo 3. Tersanelerde uygulanan radyografinin risk değerlendirme tablosu

\begin{tabular}{|c|c|c|c|}
\hline TEHLIKE & OLASILIK & $\begin{array}{l}\text { ŞIDDET } \\
\text { SEVIYESi }\end{array}$ & SONUÇ \\
\hline Operatörlerin yetersiz saha hakimiyeti & 5 & 4 & 20 \\
\hline Gama-ışın kaynağının hortum içerisinde sıkışması & 4 & 4 & 16 \\
\hline Aktif doz ölçüm cihazlarının doğru ölçüm yapmaması & 3 & 5 & 15 \\
\hline Aktif doz ölçüm cihazının bataryasının bitmesi & 3 & 5 & 15 \\
\hline Yönlendirici (collimator) kullanılmaması & 5 & 3 & 15 \\
\hline Muayene sırasında doz ölçüm cihazlarının kullanılmaması & 3 & 4 & 12 \\
\hline Denetim alanının yanlış belirlenmesi & 4 & 3 & 12 \\
\hline Pasif doz ölçüm cihazlarının doğru kullanılmaması & 4 & 3 & 12 \\
\hline Operatörler arasındaki iletişim eksikliği & 3 & 4 & 12 \\
\hline Çekim bölgesinin yetersiz aydınlatılması & 3 & 4 & 12 \\
\hline Atmosferik etkilerden çekim bölgesinin korunamaması & 3 & 4 & 12 \\
\hline Risk değerlendirmesinin radyasyondan korunmayı kapsamaması & 3 & 4 & 12 \\
\hline Operatörlerin yetersiz denetlenmesi & 5 & 2 & 10 \\
\hline $\begin{array}{l}\text { Tersane personelinin radyasyon ve etkileri hakkında bilgi sahibi } \\
\text { olmaması }\end{array}$ & 5 & 2 & 10 \\
\hline Gama-ışın kapsülündeki radyasyon sızıntısı & 2 & 5 & 10 \\
\hline İş planlaması eksikliği & 4 & 2 & 8 \\
\hline $\begin{array}{l}\text { Denetimli alanın şeritlerle ayrılarak giriş çıkış kontrolünün } \\
\text { yapılmaması }\end{array}$ & 2 & 3 & 6 \\
\hline Çekim bölgesinin sesli ve ışıklı uyarı işaretleriyle donatılmaması & 2 & 3 & 6 \\
\hline Çekim bölgesinde ilgisiz kişilerin çalışma yapması & 2 & 3 & 6 \\
\hline Radyoizotopun kontrolden çıkması, kaybolması & 1 & 5 & 5 \\
\hline $\begin{array}{l}\text { Radyasyon kaynağı cihazların radyolojik olmayan etkenler } \\
\text { tarafından zarar görmesi }\end{array}$ & 1 & 5 & 5 \\
\hline Eğitimsiz ve yetkisiz kişilerin çalışması & 1 & 4 & 4 \\
\hline X-ışın cihazlarında ışının durmaması & 1 & 4 & 4 \\
\hline X-ışın cihazlarının aşırı ısınması & 3 & 1 & 3 \\
\hline
\end{tabular}

\section{Sonuç}

Tersanelerde, özellikle gemi inşa projelerindeki kaynakların tahribatsız muayenesinde kullanılan radyografi iş sağlığı ve güvenliği bakımından bünyesinde ciddi riskler barındırmaktadır. Saha radyografisinin uygulandığı tersanelerde, çalışma şartlarına göre $X$ ya da gama ışın kaynakları 
kullanılmaktadır. Yapılan risk değerlendirmesinde radyasyon kaynağı açısından bakacak olursak; $\mathrm{X}$ ışın kaynaklarında riskin gama ışın kaynaklarına göre daha düşük olduğu belirlenmiştir. Bu nedenle yapılacak radyografi uygulamalarında eğer mümkünse $X$ ışın kaynağının kullanılmasına öncelik verilmelidir. Gama ışın kaynağı kullanılması durumunda da radyasyon, kaynak üzerinden her yöne yayılmaktadır. Bu yayııımı yönlendiriciler yardımıyla muayene bölgesine yönlendirmek, personelin iyonize radyasyonun zararlı etkilerine karşı korunmasını sağlayacaktır. Kullanılan ışın kaynağı ne olursa olsun, ortamdaki radyasyonun miktarını ölçen doz ölçüm cihazlarının aktif olarak kullanılması, riskleri minimize ederek birçok kazayı önlemektedir. Bu yüzden radyasyon ölçüm cihazları muayene işlemleri esnasında aktif olarak kullanılmalı, cihazların olası arızalarına karşı yedek cihaz bulundurulmalı, cihazların kalibrasyon ve bakımları zamanında yapılmalıdır.

Risk değerlendirmesi sonucunda acil önlem alınması gereken risk, operatörlerin yetersiz saha hakimiyetidir. Bu duruma, radyografi işleminin genelde tersane bünyesinde çalışan personel tarafından değil de tersane ortamına hâkim olmayan personel tarafından yapılıyor olması neden olmaktadır. Tersane ortamına hâkim olmayan personel, radyolojik risklerden korunmak için gerekli tedbirleri almakta zorlanacaktır. Ayrıca personel, muayene bölgesindeki radyolojik olmayan risklerin de farkında olmadığı durumlarda ciddi riskler ortaya çıkmaktadır. Tersane ortamına hâkim olmayan personel, tersanedeki diğer işlemlerde de bulunmaktadır. Ancak radyografide muayene işlemini yapan personel, aynı zamanda muayene işleminin güvenli biçimde yürütülmesinden de sorumludur. Bu durum, risk değerlendirmesindeki birçok tehlikenin kök nedeni olduğu değerlendirilmektedir. Tersanedeki tüm personelin iyonize ya da iyonize olmayan radyasyon hakkında bilgi sahibi olması ve yüksek risk barındıran radyografi işleminin güvenli bir şekilde gerçekleşmesi için gerekli eğitimleri almış olması gerekmektedir. Ayrıca tersanelerdeki iş güvenliğinden sorumlu birimlerin denetleme görevini etkin olarak yapabilmeleri için radyografi ile ilgili güvenlik hususlarına hakim olması gerekmektedir.

\section{Referanslar}

CNSC, (2014). Working Safely with Industrial Radiography, Canadian Nuclear Commission Safety Publication.

Çimen, B. (2017). İyonlaştırıcı Radyasyon ve Korunma Yöntemleri. Selçuk Üniversitesi Fen Fakültesi Fen Dergisi, 43 (2), 139-147.

Deniz Ticaret Odası, (2020). Denizcilik Sektör Raporu, İstanbul.

DuPont NDT Systems, (1993). Radiographer's Weld Interpretation Reference, DuPont, USA.

Endüstriyel Radyografide Radyasyondan Korunma ve Lisanslama Yönetmeliği, (2005). Kabul Tarihi: 08 Temmuz 2005.

Honesdom, (2021). Honesdom International Limited, Products, http://www.ndt-kits.com/SENTINEL880-Delta-Gamma-Projector-s-488-618.html [Online] [Erişim 23.05.2021].

Huatec, (2021). Huatec Group Corporation, Products, http://www.huatecgroup.com/sale-11977430steel-300kv-welding-x-ray-machine-ceramic-tube-50mm-max-penetration.html [Online] [Erişim 23.05.2021]. 
ICRP, (2007). The 2007 Recommendations of the International Commission on Radiological Protection. ICRP Publication 103. Ann. ICRP 37 (2-4). https://www.icrp.org/page.asp?id=5 [Online] [Erişim 23.05.2021].

International Atomic Energy Agency (2011). Resources, https://www.iaea.org/publications [Online] [Erişim 23.05.2021].

International Atomic Energy Agency (2014). Radiation Protection and Safety of Radiation Sources: International Basic Safety Standards, IAEA Safety Standards Series No. GSR Part 3, IAEA, Vienna.

International Atomic Energy Agency (2018). Occupational Radiation Protection, IAEA Safety Standards Series No. GSG-7, IAEA, Vienna.

NDK, (2019). Nükleer Düzenleme Kurumu, Endüstriyel Radyografi Çalışma Kılavuzu, https://ndk.org.tr/tr/hizmetlerimiz/teknik-bilgiler-kilavuzlar-yeni.html [Online] [Erişim 23.05.2021].

NDK, (2020). Nükleer Düzenleme Kurumu, Teknik Bilgiler ve Kılavuzlar, https://ndk.org.tr/tr/hizmetlerimiz/teknik-bilgiler-kilavuzlar-yeni.html [Online] [Erişim 23.05.2021].

Okumuş, D, Barlas, B., (2016). Gemi inşaatı sektöründe $5 \times 5$ analiz matrisi ve Fine-Kinney yöntemlerinin uygulamalı bir karşılaştırması, Gemi ve Deniz Teknolojisi Dergisi, (204-205): 95-106.

Pandey, A., Singh, M., Sonawane, A. U., \& Rawat, P. S. (2016). FMEA based risk assessment of component failure modes in industrial radiography. International Journal of Engineering Trends and Technology (IJETT), V39(4),216-225.

Radyasyon Güvenliği Yönetmeliği, (2000). Kabul Tarihi: 24.03.2000.

TENMAK, (2021). Türkiye Enerji, Nükleer ve Maden Araştırma Kurumu, https://www.tenmak.gov.tr [Online] [Erişim 23.05.2021].

Türk Loydu, (2019). Türk Loydu Kaynak Kuralları, Kısım 3, Cilt A.

UNSCEAR, (2021). United Nations Scientific Committee on the Effects of Atomic Radiation, Publication, https://www.unscear.org/unscear/publications.html [Online] [Erişim 23.05.2021].

Zeyrek, C. (2014). İyonize Radyasyon Uygulamaları İçin Güvenlik ve Korunmaya Yönelik Genel Kavramlar. Süleyman Demirel Üniversitesi Fen Bilimleri Enstitüsü Dergisi, 17 (3), 1-9.

Zeyrek, C. T., Akbıyık, H. (2016). Development of Human Resources Through Awareness Education and Training Activities on Occupational Radiation Protection for Industrial Radiography in Turkey, Journal of Materials Education, Volume: 38, Issue: 5-6, Pages: 191-201.

Zeyrek, C. T., Babayiğit, D. (2020). Evaluation Of Education And Training Activities On Radiation Safety in Turkey For The Five Years Period (2013-2017), International Conference on Radiation Safety: Improving Radiation Protection in Practice (virtual), IAEA Headquarters Vienna, Austria, P132. 